\title{
EFFECTS OF PERIODICAL CICADA OVIPOSITIONAL INJURY ON WOODY PLANTS
}

\author{
by Fredric Miller ${ }^{1}$ and Webster Crowley ${ }^{2}$
}

\begin{abstract}
The long-term effect of oviposition by the female periodical cicadas Magicicada septendecim and $M$. cassini (Homoptera: Cicadidae) was examined on woody plants in landscape plantings at The Morton Arboretum in northeastern Illinois following the 1991-1993 growing seasons. A minimum branch diameter of approximately $5 \mathrm{~mm}$ appears to be a critical factor in ovipositional activity. Plants with stout branching habits do not appear to be suitable for oviposition. The percent canopy flagging, as a function of the number of wounds per branch, may not be an accurate measurement of ovipositional damage. Young trees with stem diameters or main scaffold branches with diameters between 5 and $10 \mathrm{~mm}$ may experience significant damage to the main trunk, resulting in breakage and significant growth loss. Larger plant material does not appear to be significantly affected by ovipositional damage, but it does result in a minor natural pruning event.
\end{abstract}

During late May and early June 1990, the northern one-third of Illinois experienced the emergence of the Northern Illinois Brood (Marlatt's XIII) of the 17-year periodical cicadas Magicicada septendecim and M. cassini (Stannard 1975). Periodical cicadas are found only in the deciduous forest areas of the eastern one-third of the United States with extensions into the Plains states (Dybas 1973). After developing for almost 17 years underground, the nymphs emerge, shed their skin, and become adults. After mating, the adult female begins depositing eggs in the woody tissue of shrubs and trees. Plant damage results when the female cicada deposits eggs into twigs and branches. The ovipositional wound is generally a slit in the bark tissue but may widen to form a rather large wound. Twigs that are weakened by these wounds are more likely to die later in the summer and litter the ground by breaking off during wind storms. On older, well-established trees, branch flagging may result, but the damage is not considered serious. On very young trees, small shrubs, and nursery stock, serious damage to branch terminals and/or the trunk may occur (Cutright and Parks 1949; Hamilton 1953; Graham and Cochran
1954; Graham and Krestensen 1957; Forsythe 1966; Hogmire et al. 1990).

Few studies have been conducted on the impact of periodical cicada ovipositional damage on woody landscape plants. Most previous studies focused on fruit trees and orchard management. Smith and Linderman (1974) rated deciduous and evergreen ornamental trees and shrubs in Maryland attacked by Brood $X$ of the periodical cicada. They found that wound closure varied, depending on the plant genera, from none to rough partial closure with stunted growth and reduced flowering, to rapid closure and complete recovery.

Little is known about the potential immediate and long-term impact of ovipositional damage to the trunks and growing stems of young woody landscape plants and trees or the possible longterm effects of such "natural pruning" by the periodical cicada. Therefore, a study was initiated to determine: 1) which genera of woody plants were attacked by the periodical cicada; 2) basic ovipositional wound characteristics such as maximum branch diameter, minimum branch diameter, wound width, wound length, number of wounds per branch, and percent canopy flagging; 3 ) plant response to wounding and rate of wound closure; and 4) long-term effects, if any, of ovipositional damage on overall plant health, including predisposition to wound-invading insects and pathogens.

\section{Materials and Methods}

Wounding. Beginning in August 1990, following the cessation of ovipositional activity, an extensive examination of 140 exotic and native woody plant genera growing at The Morton Arboretum, Lisle, Illinois, was conducted for evidence of ovipositional damage. Of these, 16 common woody landscape plant genera were selected for more intensive examination. Ten plants were sampled for each genus. (A list of genera included 
in the study can be found in Table 3.) All study sites had a history of previous heavy 17-year periodical cicada emergence events and contained plant material representative of northern Illinois.

On each native and exotic plant (experimental unit), 1 branch from each of 4 quadrants $(N, S$, $E$, and $W$ ) was randomly selected. On each branch selected, the maximum branch diameter (MXBD) where wounding began, minimum branch diameter (MNBD) where wounding ceased, wound length (WL), wound width (WW), and total number of wounds per branch (WPB) were recorded. The MXBD and MNBD were measured (to the nearest $\mathrm{mm}$ ) using a handheld vernier caliper. Wound width and length were measured by arbitrarily selecting 1 wound on each branch. Measurements were taken at the longest point of the wound length (nearest $\mathrm{cm}$ ) and the widest point of the wound (nearest $\mathrm{mm}$ ). Percent canopy flagging (PCF) was evaluated visually by 2 independent estimates and averaged using a scale of 0 to 10 at $10 \%$ increments with 0 $=$ no apparent flagging and $10=100 \%$ canopy flagging. No attempt was made to distinguish between ovipositional damage caused by the 2 cicada species.

Wound closure. Wound width was measured in all 140 genera in 1990 and again in 1993. To evaluate long-term woody landscape plant response to wounding and subsequent wound closure, WW measurements, as described above, were taken following the 1991, 1992, and 1993 growing seasons for the 16 genera selected for more intensive study. Wounds that had completely callused over were considered closed.

Statistical analysis. Data were subjected to a multivariate analysis of variance (MANOVA) for genera for all dependent variables. Individual plants were identified as the experimental unit and were considered replicates. A lack of wound data (WPB) for certain genera at The Morton Arboretum created an unbalanced data set for this variable; therefore, a mixed-model, 2-level nested ANOVA was performed. Data were analyzed using Systat 5.0 for Windows (1992) and Statistix 4.0 Analytical Software (1992).

\section{Results}

Wounding. The initial survey (late summer $1990)$ revealed that 43 native and exotic woody plant families, including 75 native genera and 65 exotic genera, experienced some degree of ovipositional damage (Table 1). Three gymnosperm families, including 5 genera, exhibited ovipositional damage. Seven plant genera had extensive wounding and 9 plant genera experienced twig breakage. The plant list presented is by no means complete, but it does represent a comprehensive and extensive sampling of woody plant genera growing in northeastern Illinois.

A total of 16 woody plant genera, including 8 angiosperms and 8 gymnosperms, were not damaged by the periodical cicada even though they were surrounded by plants that were heavily damaged (Table 1).

There were no significant differences in wound characteristics for the 140 genera initially examined. Overall, plants had a MXBD of approximately $8.14 \mathrm{~mm}$ and a MNBD of $5.44 \mathrm{~mm}$. Wound length for each group was $5.9 \mathrm{~cm}$ and $W W$ was $5.56 \mathrm{~mm}$. Both native and exotic plants had a mean of 4 wounds per branch and a percent canopy flagging of $10 \%$ to $12 \%$.

Multivariate analysis of variance (MANOVA) suggested that genera were affected significantly $(P>0.001)$ by the dependent variables of MXBD, MNBD, WL, WW, and PCF. The mixed-model 2level nested analysis of variance (ANOVA) revealed that taxa were also significantly $(P=$ 0.0001 ) affected by the dependent variable of WPB.

Ovipositional wound characteristic measurement values were quite variable among woody landscape plant genera. Overall, mean branch diameter at which wounding began (MXBD) was $9.12 \mathrm{~mm}$; minimum branch diameter at which wounding ended (MNDB) was $4.99 \mathrm{~mm}$ (Table 2). Mean wound length (WL) was $6.17 \mathrm{~cm}$ and mean wound width (WW) was $5.10 \mathrm{~mm}$ (Table 2). Woody landscape plants in this study had a mean of 7 wounds per branch (WPB), and the mean percent canopy flagging (PCF) was $14 \%$ (Table 2). 
Table 1. Woody plant genera exhibiting ovipositional damage and those not attacked by the adult female periodical cicada, The Morton Arboretum, August 1990.

\begin{tabular}{|c|c|}
\hline \multicolumn{2}{|c|}{ Angiosperms } \\
\hline Family & Genera \\
\hline Aceraceae & $A c e r^{\mathrm{ab}}$ \\
\hline \multirow[t]{2}{*}{ Anacardiaceae } & Cotinus ${ }^{c}$ \\
\hline & Rhus glabra \\
\hline Annonaceae & Asimina triloba \\
\hline Aquifoliceae & $11 e x^{c}$ \\
\hline \multirow[t]{2}{*}{ Asteraceae } & Baccharis \\
\hline & Chysothamnus ${ }^{c}$ \\
\hline \multirow[t]{2}{*}{ Berberidaceae } & Berberis spp. \\
\hline & Mahonia $^{\mathrm{c}}$ \\
\hline \multirow[t]{4}{*}{ Betulaceae } & Alnus \\
\hline & Betula $^{c}$ \\
\hline & Carpinus ${ }^{a}$ \\
\hline & Ostrya $a^{\mathrm{a}}$ \\
\hline Bignoniaceae & Catalpa \\
\hline Buxaceae & $B u x u s^{c}$ \\
\hline Caesalpinioidae & Gymnocladus dioicus \\
\hline Calycanthaceae & Calycanthus \\
\hline \multirow[t]{3}{*}{ Caprifoliaceae } & Lonicerac \\
\hline & Viburnum \\
\hline & Weigela \\
\hline \multirow{2}{*}{ Celastraceae } & Euonymus \\
\hline & Euonymus alatus \\
\hline Cercidiphyllacea & Cercidphyllumb \\
\hline Cornaceae & Cornus \\
\hline Corylaceae & Corylus avellana \\
\hline \multirow[t]{2}{*}{ Cupressaceae } & Juniperus \\
\hline & Thujac \\
\hline Ebenaceae & Diospyros \\
\hline \multirow[t]{2}{*}{ Ericaceae } & Oxydendron \\
\hline & Rhododendronc \\
\hline Eucommiaceae & Eucommia $^{\mathrm{c}}$ \\
\hline Ginkgoaceae & Ginkgoc \\
\hline \multirow[t]{3}{*}{ Fagaceae } & Castanea $^{a}$ \\
\hline & Fagus $^{b}$ \\
\hline & Quercus ${ }^{\mathrm{a}}$ \\
\hline \multirow[t]{2}{*}{ Hamamelidaceae } & Corylopsisc \\
\hline & Hamamelis \\
\hline \multirow{3}{*}{$\begin{array}{l}\text { Hippocastanaceae } \\
\text { Juglandaceae }\end{array}$} & Aesculus ${ }^{\circ}$ \\
\hline & Carya \\
\hline & Juglansc \\
\hline \multirow[t]{2}{*}{ Lauraceae } & Lindera $^{c}$ \\
\hline & Sassafras $^{\circ}$ \\
\hline \multirow[t]{3}{*}{ Leguminosae } & Cercis $^{b}$ \\
\hline & Genista $^{c}$ \\
\hline & Gleditsiac $^{c}$ \\
\hline \multirow[t]{2}{*}{ Magnoliaceae } & Liriodendron \\
\hline & Magnoliac \\
\hline
\end{tabular}

\begin{tabular}{|c|c|}
\hline \multicolumn{2}{|c|}{ Angiosperms } \\
\hline Family & Genera \\
\hline Moraceae & $\begin{array}{l}\text { Maclura pomifera } \\
\text { Morus }\end{array}$ \\
\hline Myrica & $\begin{array}{l}\text { Comptonia } \\
\text { Myrica }^{\mathrm{a}}\end{array}$ \\
\hline Oleaceae & $\begin{array}{l}\text { Chionanthus } \\
\text { Forestieria }^{\mathrm{b}} \\
\text { Forsythia }^{\mathrm{c}} \\
\text { Fraxinus }^{\circ} \\
\text { Syringa }^{\mathrm{c}}\end{array}$ \\
\hline Paeoniaceae & Paeonia ${ }^{c}$ \\
\hline Pinaceae & $\begin{array}{l}\text { Abies spp. } \\
\text { Larix spp. } \\
\text { Picea abies } \\
\text { Picea pungens } \\
\text { Pinus nigra } \\
\text { Pinus strobus } \\
\text { Pinus sylvestris } \\
\text { Pseudotsuga menziesii } \\
\text { Tsuga }\end{array}$ \\
\hline Platanaceae & Platanus $^{c}$ \\
\hline Rosaceae & $\begin{array}{l}\text { Amelanchier } \\
\text { Aronia }^{\mathrm{b}} \\
\text { Chaenomeles }^{\mathrm{c}} \\
\text { Crataegus }^{b} \\
\text { Malus }^{\mathrm{c}} \\
\text { Prunus }^{\mathrm{a}} \\
\text { Pyrus }^{\mathrm{a}} \\
\text { Rosa }^{\mathrm{b}} \\
\text { Spiraea }^{c}\end{array}$ \\
\hline Rutaceae & Phellodendron amurense \\
\hline Salicaceae & $\begin{array}{l}\text { Populus } \\
\text { Salix }\end{array}$ \\
\hline Sapindaceae & Koelreuteriac \\
\hline Saxifragaceae & $\begin{array}{l}\text { Hydrangea } \\
\text { Ribes }^{c}\end{array}$ \\
\hline Simaroubaceae & Ailanthus ${ }^{c}$ \\
\hline Styracaceae & Halesiac \\
\hline Taxaceae & Taxus ${ }^{c}$ \\
\hline Thymelaeaceae & Dirca $^{\complement}$ \\
\hline Tiliaceae & Tiliac \\
\hline Ulmaceae & $\begin{array}{l}\text { Celtis } \\
\text { Ulmus }\end{array}$ \\
\hline
\end{tabular}

aPlant genera with heavy ovipositional damage.

bPlant genera with heavy twig breakage.

'Plant genera attacked, but with minimal damage;

unmarked genera were not attacked. 
Table 2. Summary of ovipositional wound characteristics by the periodical cicada on selected woody landscape plant genera at The Morton Arboretum, August 1990.

\begin{tabular}{lll}
\hline Variable & Mean & Range \\
\hline $\begin{array}{c}\text { Maximum diameter } \\
\text { (MXBD) }\end{array}$ & $9.12 \mathrm{~mm}$ & $7.16-10.89 \mathrm{~mm}$ \\
$\begin{array}{c}\text { Minimum diameter } \\
\text { (MNBD) }\end{array}$ & $4.99 \mathrm{~mm}$ & $3.84-7.28 \mathrm{~mm}$ \\
Wound length (WL) & $6.17 \mathrm{~cm}$ & $4.12-7.46 \mathrm{~cm}$ \\
$\begin{array}{l}\text { Wound width (WW) } \\
\text { Wounds per }\end{array}$ & $5.10 \mathrm{~mm}$ & $3.58-6.54 \mathrm{~mm}$ \\
$\quad$ branch (WPB) & & $4-11$ \\
$\begin{array}{c}\text { Percent canopy } \\
\text { flagging (PCF) }\end{array}$ & $14 \%$ & $8 \%-30 \%$ \\
\hline
\end{tabular}

Wound closure. An ovipositional wound followup survey, conducted in fall 1993, revealed that 42 genera of native plants had a mean WW of $1.66 \mathrm{~mm}$, with $38 \%$ of the plant genera having complete wound closure. Percent wound width reduction (WWR) at the end of the 1993 growing season was $78 \%$ of the initial 1990 WWs.

In comparison, 44 exotic plant genera were re-examined in late 1993. The mean WW was $1.20 \mathrm{~mm}$, with $52 \%$ of the plant genera having complete wound closure. Percent WWR for the exotic plants was $80 \%$ by the end of 1993 .

Of the original 16 woody landscape plant genera surveyed at the end of the 1991 growing season, 11 genera had a mean WWR of at least $50 \%$. Cornus, Forsythia, and Salix had complete wound closure after 1 growing season; Magnolia, Malus, and Quercus had WWR of $90 \%$ or greater (Table 3). By the end of the 1992 growing season, $91 \%$ of the plant genera with a mean WWR of $50 \%$ or greater at the end of the 1991 growing season had total wound closure (Table 3 ). The single exception was Alnus, which had not closed its wounds. After the 1993 growing season, all but Cercus, Juglans, and Tilia had closed their wounds (Table 3 ).

\section{Discussion}

Wounding. The periodical cicada appears capable of ovipositing on a wide variety of native and exotic woody plants. The vast majority of the plants used by the cicada are angiosperms. Woody understory and tree genera were used equally.
Our results are similar to Skeels (1907) who, while observing the 1905 emergence near Joliet, Illinois, reported that Juglans, Carya, Salix, Populus, Quercus, Alnus, Celtis, Ulmus, Acer, Fraxinus, Prunus, Rosa, Viburnum, and Cornus experienced some degree of ovipositional damage, with Quercus, Rosa, and Acerbeing heavily attacked. In our study, Quercus, Acer, and Prunus experienced heavy ovipositional damage, and Acer, Rosa, Sorbus, and Crataegus had extensive twig breakage. Smith and Linderman (1974) also reported heavy ovipositional damage and twig breakage on the above genera in a Maryland nursery. In our study, Maclura pomifera was not attacked, as also reported by White (1980).

Our field observations revealed that some plants (i.e., Pinus spp., Ailanthus altissima, Rhus typhina, and Gymnocladus dioicus) were not attacked even though surrounded by damaged plant material. Skeels (1907) believed that the cicadas avoided the coniferae because of some inherent quality within these trees. Based on our observations in this study, it is possible that leaf arrangement on the twigs and branches of certain conifers and evergreens may deter ovipositional activity. Plants with needles or leaf scales

Table 3. Ovipositional wound width reduction (WWR) expressed as a cumulative percentage for common woody landscape plant genera at The Morton Arboretum for the 1991-1993 growing seasons.

\begin{tabular}{|c|c|c|c|c|}
\hline \multirow{2}{*}{$\begin{array}{l}\text { Plant } \\
\text { genera }\end{array}$} & \multirow{2}{*}{$\begin{array}{l}\text { WW (mm) } \\
1990\end{array}$} & \multicolumn{3}{|c|}{ Cumulative $\%$ WW reduction $(\mathrm{mm})^{\mathrm{a}}$} \\
\hline & & 1991 & 1992 & 1993 \\
\hline Acer & 5.40 & 51.9 & $100.0(C)^{b}$ & - \\
\hline Alnus & 5.45 & 50.5 & 0.0 & $100.0(C)$ \\
\hline Catalpa & 5.37 & 81.3 & $100.0(\mathrm{C})$ & 一 \\
\hline Cercis & 3.78 & 41.8 & 67.7 & 92.2 \\
\hline Cornus & 6.32 & $100.0(\mathrm{C})$ & - & - \\
\hline Crataegus & 3.91 & 33.5 & $100.0(\mathrm{C})$ & - \\
\hline Forsythia & 6.08 & $100.0(\mathrm{C})$ & - & 一 \\
\hline Fraxinus & 3.80 & 23.7 & $100.0(\mathrm{C})$ & - \\
\hline Juglans & 3.47 & 16.4 & 38.8 & 78.4 \\
\hline Magnolia & 6.54 & 96.9 & $100.0(\mathrm{C})$ & - \\
\hline Malus & 5.39 & 92.6 & $100.0(\mathrm{C})$ & - \\
\hline Prunus & 6.08 & 68.8 & $100.0(\mathrm{C})$ & - \\
\hline Quercus & 6.40 & 93.8 & $100.0(\mathrm{C})$ & - \\
\hline Salix & 5.08 & $100.0(\mathrm{C})$ & - & 一 \\
\hline Sorbus & 5.02 & 60.2 & $100.0(C)$ & 一 \\
\hline Syringa & 3.58 & 7.8 & 0.0 & 92.2 \\
\hline Tilia & 7.66 & 26.9 & 52.1 & 70.2 \\
\hline Mean & 5.10 & 52.8 & 75.6 & 86.6 \\
\hline
\end{tabular}

apercent wound width reduction (WWR) is the percent reduction in wound width as compared to the wound width of the previous growing season. $\mathrm{b}(\mathrm{C})=$ Wound had closed. 
that did not entirely encircle the twig or branch and that were somewhat pliable or flexible (e.g., hemlock, juniper, arborvitae, and yew) were more likely to be attacked by the adult female. Plants with stiffer or less flexible needles completely encircling the twig or branch (e.g., spruce, pine, and fir) were not attacked.

In addition, the degree of resin production and flow could be involved, but that factor was not investigated in this study. White et al. (1982) observed that eggs laid in white pine and hemlock twigs had a lower hatching rate, as compared to deciduous plants. This difference appears to be a function of resin production. Junipers, which have a thinner and lower resin flow, had egg hatch rates comparable to redbud and pin oak, both deciduous plants. Fewer egg nests on juniper twigs were completely sealed with resin, as compared to pines and hemlock. Marlatt (1907) speculated that poor hatching success in pines is probably due to resin and that resin secretion imprisons the eggs within the twig and prevents egg hatch and escape of nymphs from the egg nest. White et al. (1982) observed fewer egg nests on evergreen species, as compared to deciduous plants. We observed that many of the typical deciduous plants, including Acer, Tilia, Malus, and Prunus, had much higher numbers of egg nests, which resulted in continual wounding down the length of the branch. It appears that female periodical cicadas prefer deciduous plants to evergreens for oviposition.

In addition to leaf arrangement, branch diameter also affects ovipositional activity. Ailanthus altissima, G. dioicus, and Rhus spp., which possess thick, stout branches with diameters approaching $10 \mathrm{~mm}$, were not attacked. This equals or exceeds the mean MXBD $(9.12 \mathrm{~mm})$, the point at which wounding had ceased on many of the woody plants surveyed in this study. Field observations revealed that the adult female periodical cicada attempted to oviposit in the leaf rachis of $G$. dioicus. These rachis are approximately $4 \mathrm{~mm}$ in diameter, comparable to the mean MNBD of $5 \mathrm{~mm}$, the point at which wounding ceased on other woody plant genera. White (1980) states that few periodical cicada eggs were laid in twigs larger than $11 \mathrm{~mm}$ or smaller than $3 \mathrm{~mm}$. Of the 22,799 egg nests examined by White (1980), only $11(0.05 \%)$ were found in twigs larger than $11 \mathrm{~mm}$ and $746(3.3 \%)$ in twig sizes less than $3 \mathrm{~mm}$ in diameter. The percent canopy flagging for woody landscape plants in this study was approximately $14 \%$.

Wound closure. Long-term effects of cicada ovipositional damage appeared to affect native and exotic plants in a similar fashion as evidenced by WWR values after 4 growing seasons.

Wound width reduction (WWR) for woody landscape plants varied by genera. Wounds on Salix closed by the end of the second growing season, and wounds on Acer, Fraxinus, Malus, and Quercus closed by the end of the third growing season. These results are consistent with the same genera of tree species growing in nearby communities (Miller 1997). Basswood was consistently slow in wound healing both in this study and in the nearby study (Miller 1997). Skeels (1907) commented that wounds in willows (Salix spp.) close so rapidly that young cicadas might find themselves enclosed. In contrast, basswood (Tilia) are known to be slow wound closers.

\section{Conclusions}

Ovipositional damage does not appear to be detrimental to native or exotic woody landscape plants as observed in this study. Other than natural pruning, no significant long-term effects were observed due to ovipositional wounding. The periodical cicada does not appear to be a major threat to the health and vitality of the woody plant genera examined in this study.

\section{Literature Cited}

Cutright, C.B., and C.V. Parks. 1949. Combating the periodical cicada with insecticides. J. of Econ. Entomol. Vol. 42:359-362.

Dybas, H. 1973. It's the year of the cicada in these parts. Field Mus. Nat. Hist. Bull. 44(5): 1-8.

Forsythe, H.Y., Jr. 1966. Screening insecticides for control of the adult periodical cicada. J. Econ. Entomol. 59:413-416.

Graham, C., and A.B. Cochran. 1954. The periodical cicada in Maryland in 1953. J. Econ. Entomol. 47:242-244.

Graham, C., and E.R. Krestensen. 1957. A residual spray for the control of the periodical cicada. J. Econ. Entomol. 50: 713-715. 
Hamilton, D.W. 1953. Notes on the activity and control of the periodical cicada, 1945 and 1950. J. Econ. Entomol. 46:385.

Hogmire, H.W., T.A. Baugher, V.L. Crim, and S.I. Walter. 1990. Effects and control of periodical (Homoptera: Cicadidae) oviposition injury on nonbearing apple trees. J. Econ. Entomol. 83: 2401-2404.

Marlatt, C.L. 1907. The periodical cicada. Bull. U.S. Dept. Agric. Bur. Ent. $71.181 \mathrm{pp}$.

Miller, F.D. 1997. Effects and control of periodical cicada Magicicada septendecim and Magicicada cassini oviposition injury on urban forest tree species. J. Arboric. 23:(6):225-232.

Skeels, H.C. 1907. Trees injured by the seventeenyear cicada. Am. Bot. 12:9-17.

Smith, F.F., and R.G. Linderman. 1974. Damage to ornamental trees and shrubs resulting from oviposition by periodical cicada. Environ. Entomol. 3:725-732.

Stannard, L.J., Jr. 1975. The distribution of periodical cicadas in Illinois. III. Nat. Hist. Surv. Biol. Notes \#91. 12 pp.

White, J. 1980. Resource partitioning by ovipositing cicadas. Am. Nat. 115(1):1-28.

White, J., M. Lloyd, and R. Carbine. 1982. Why don't periodical cicadas normally live in coniferous forests? Environ. Entomol. 11:475-482.

Acknowledgements. The authors wish to thank A. Sanborn of Barry University, R. Brandt of Wheaton College, and C. Dunn of The Morton Arboretum for their helpful comments on an earlier version of this manuscript. Special appreciation and thanks is due to C. Whelan, The Morton Arboretum, for his invaluable assistance and consultation with statistical analysis. A special note of thanks is extended to D. Kuzwara, $\mathrm{S}$. Uetz, and members of The Morton Arboretum research staff for their assistance in collecting field data, and J. Hammershaimb and K. von der Heide-Spravka for their help with data entry. A personal note of thanks and appreciation is extended to my wife, M. Miller, for her invaluable assistance in all aspects of this project.

\section{'University of IIIinois \\ Countryside Extension Center \\ 6438 Joliet Road \\ Countryside, IL 60525}

\author{
${ }^{2}$ The Morton Arboretum \\ 4100 Route 53 \\ Lisle, IL 60532
}

Résumé. L'effet à long terme de l'oviposition par l'insecte femelle de cicadelles, Magicicada septendecim et $M$. cassini (homoptères: Cicadidae), a été étudié sur des plantes ligneuses de l'arboretum Morton dans le Nord-Est de l'llinois. Le diamètre minimum de la branche apparaît être un facteur critique pour l'oviposition. Les plantes avec de grosses branches épaisses ne sont pas apparu favorables pour l'oviposition. Le pourcentage de cime affecté, c'est-à-dire le nombre de blessures par branche, ne serait pas une mesure précise des dommages par l'oviposition. Les jeunes arbres avec des tiges ou des branches principales entre 5 et 10 $\mathrm{mm}$ de diamètres peuvent être sujet à des dommages significatifs sur le tronc principal qui résultent à des bris et des pertes significatives de croissance. Les végétaux de plus grandes dimensions n'ont pas apparu être significativement affectés par les dommages de l'oviposition mais il en résulte néanmoins une élagage naturel mineur. Même de sévères et importants dommages d'oviposition n'apparaissent pas prédisposer les grands arbres et arbustes à une attaque par des insectes ou des maladies secondaires.

Zusammenfassung. Im Morton Arboretum im nordöstlichen Illinois wurde der Langzeiteffekt der Eiablage bei der weiblichen Zikade Magicicada septendecium und $M$. cassini (Homoptera: Cicadidae) auf hölzernen Pflanzen untersucht. Der minimale Astdurchmesser erwies sich als kritischer Fakton bei der Eiablageaktivität. Pflanzen mit gedrungenen Verzweigungsmuster schienen für die Eiablage nicht geeignet zu sein. Der Anteil der Welkeerscheinungen in der Krone also ein Resultat aus der Anzahl der Wunden pro Ast ist kein geeignetes Meßinstrument für das Schadensausmaß durch die Eiablage. Junge Bäume mit einmen Stammdurchmesser oder kronenbildende Äste mit Durchmessern zwischen 5 und $10 \mathrm{~mm}$ können einen deutlichen Schaden am Hauptstamm durch Stammbruch und Wachstumsverlust erfahren Größeres Pflanzenmaterial scheint nicht besonders durch die Eiablage beeinflußt zu sein, es kann aber zu vermehrter Selbstastung kommen. Auch schwere und heftige Schäden durch Eiablage scheinen größere Sträucher und Bäume nicht für eine sekundäre Attacke durch Insekten oder Pathogene anfällig zu machen.

Resumen. Fue examinado el efecto a largo plazo por la oviposición de las hembras de cigarras periódicas, Magicicada septendecim y $M$. cassini (Homoptera: Cicadidae) sobre plantas leñosas en plantaciones en el paisaje en el Morton Arboretum en el noreste de Illinoins. EI diámetro minímo de la rama parece ser un factor crítico en la actividad de oviposición. Las plantas sin fuertes hábitos de ramificación no parecen ser apropiadas para la oviposición. El por ciento de copa en bandera, como una función del número de heridas por rama, no parece ser una medida precisa del daño por oviposición. Los árboles jóvenes con diámetros de ramas o ramas principales entre 5 y 10 $\mathrm{mm}$ pueden experimentar daño significativo al tronco principal resultando en resquebrajamiento y pérdida de crecimiento. El material de plantas grandes no parece ser afectado significativamente por el daño por oviposición, pero resulta en menor poda natural. De igual modo el daño severo y pesado por oviposición no parece predisponer a los árboles y grandes arbustos leñosos a ataques de insectos secundarios o patógenos. 